\title{
A MODEST REFORM FOR FEDERAL PROCEDURAL RULEMAKING
}

\author{
CARL TOBIAS*
}

The Judicial Conference of the United States Advisory Committee on Civil Rules (the "Advisory Committee"), which has primary responsibility to study the Federal Rules of Civil Procedure (the "Federal Rules") and to formulate recommendations for improvement, recently developed a thorough package of revisions to the Federal Rules that govern discovery. ${ }^{1}$ During April 2000, the United States Supreme Court promulgated essentially intact the set of amendments that the Advisory Committee had proposed. ${ }^{2}$ Those changes became effective in December $2000 .^{3}$

The rule revision entities commissioned discovery studies, developed proposals, and solicited and considered extensive public input on the recommended alterations to the Federal Rules. Despite concerted effort, the efficacy of the new amendments remains unclear, partly because federal district courts have not actually applied them. The revisions, this deficiency in the amendment process, and prospects for its remediation warrant analysis.

The efforts to revise the rules commenced several years ago. In 1996, the Advisory Committee appointed a Discovery Subcommittee that it asked to explore the prospect of additional changes to the Federal Rules' discovery provisions, a number of which the Supreme Court had amended as recently as $1993 .{ }^{4}$ The Discovery Subcommittee investigated the necessity of further altering the discovery provisions, in part by commissioning several assessments that two expert en-

Copyright $@ 2001$ by Carl Tobias

This comment is also available at http://www.law.duke.edu/journals/64LCPTobias.

* Professor of Law, William S. Boyd School of Law, University of Nevada, Las Vegas.

I wish to thank Michael Higdon, Peggy Sanner, and Jeff Stempel for valuable suggestions, Angela Dufva for processing this piece, and Jim Rogers for generous, continuing support. Errors that remain are mine.

1. See Committee on Rules of Practice and Procedure of the Judicial Conference of the U.S., Proposed Amendments to the Federal Rules of Civil Procedure and Evidence, 181 F.R.D. 18 (1999) [hereinafter Proposed Amendments]. See generally Elizabeth G. Thornburg, Giving the "Haves" a Little More: Considering the 1998 Discovery Proposals, 52 SMU L. REV. 229 (1999); Carl Tobias, Discovery Reform Redux, 31 CONN. L. REV. 1433 (1999).

2. See Amendments to Federal Rules of Civil Procedure, 192 F.R.D. 340 (2000).

3. The revisions took effect because Congress did not exercise its authority under the Rules Enabling Act to alter them. See 28 U.S.C. § 2074(a) (1994). See generally Stephen B. Burbank, The Rules Enabling Act of 1934, 130 U. PA. L. REV. 1015 (1982); Carl Tobias, Improving the 1988 and 1990 Judicial Improvements Acts, 46 STAN. L. REV. 1589, 1599-1600 (1994).

4. See Order Amending the Federal Rules of Civil Procedure, 507 U.S. 1091 (1993); Paul V. Niemeyer, Here We Go Again: Are The Federal Discovery Rules Really in Need of Amendment?, 39 B.C. L. REV. 517, 521 (1998) [hereinafter Niemeyer, Here We Go Again]; Memorandum from Paul V. Niemeyer, Chair, Advisory Committee on Civil Rules to Alicemarie H. Stotler, Chair, Committee on Rules of Practice and Procedure, 181 F.R.D. 24, 25 (1999) [hereinafter Stotler Memorandum]. 
tities conducted. One of these institutions was the Federal Judicial Center (the "FJC"), the principal research arm of the federal courts. ${ }^{5}$ The second body was the Institute for Civil Justice of the RAND Corporation (the "ICJ"), which had recently completed a comprehensive evaluation of the procedures for reducing expense and delay adopted and enforced by the ninety-four federal district courts under the Civil Justice Reform Act (the "CJRA") of 1990. ${ }^{6}$ The FJC and the ICJ collected and analyzed considerable empirical data on the application and operation of the 1993 revisions of the Federal Rules.

The Advisory Committee substantially relied on those studies in formulating a group of proposed amendments to the discovery rules for the consideration of the Judicial Conference Committee on Rules of Practice and Procedure (the "Standing Committee"), ${ }^{8}$ which reviews proposals developed by the advisory committees on appellate, bankruptcy, civil, criminal, and evidentiary rules. The Standing Committee instituted few modifications to the Advisory Committee draft and published proposed revisions on which it sought public input.' The Standing Committee then evaluated the public comments, minimally changed the suggested alterations, and, in 1999, compiled a final package of proposed amendments for the Judicial Conference, the policymaking arm of the federal courts. ${ }^{10}$ The Conference made one modification in the set that the Advisory Committee tendered ${ }^{11}$ and submitted the

5. See 28 U.S.C. $§ 620$ (1994). See generally William W Schwarzer, The Federal Judicial Center and the Administration of Justice in the Federal Courts, 28 U.C. DAVIS L. REV. 1129 (1995); Russell Wheeler, Empirical Research and the Politics of Judicial Administration: Creating the Federal Judicial Center, 51 LAW \& CONTEMP. PROBS. 31 (Summer 1988).

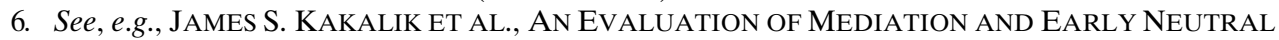
EVAluation UNDER THE Civil Justice ReForm ACT (1996); JAMES S. KAKALIK ET AL., Just, SPEEDY, AND INEXPENSIVE? AN EVALUATION OF JUDICIAL CASE MANAGEMENT UNDER THE CIVIL JUSTICE REFORM ACT (1996). See generally Tobias, supra note 3.

7. See James S. Kakalik et al., Discovery Management: Further Analysis of the Civil Justice Reform Act Evaluation Data, 39 B.C. L. REV. 613 (1998); Thomas E. Willging et al., An Empirical Study of Discovery and Disclosure Practice Under the 1993 Federal Rule Amendments, 39 B.C. L. REV. 525 (1998); see also Memorandum from Paul V. Niemeyer, Chair, Advisory Committee on Civil Rules to Anthony H. Scirica, Chair, Committee on Rules of Practice and Procedure, 192 F.R.D. 354, 357-58 (2000) [hereinafter Scirica Memorandum].

8. See Terry Carter, The Latest Discovery Mission: Judges Set to Debate Changes That Would Make New Federal Rules Mandatory, 85 A.B.A. J. 20 (Sept. 1999); Stotler Memorandum, supra note 4, at 24. The Advisory Committee rejected, on a 9-4 vote, deletion of the provision that would narrow discovery's scope. See Scirica Memorandum, supra note 7, at 359-60; see also John S. Beckerman, Confronting Civil Discovery's Fatal Flaws, 84 MinN. L. REV. 505, 542 n.154 (2000).

9. See generally Proposed Amendments, supra note 1.

10. The Standing Committee rejected, on a 10-2 vote, deletion of the provision that would narrow the scope of discovery. See Letter from Richard H. Middleton, Jr., President, Association of Trial Lawyers of America to William H. Rehnquist, Chief Justice of the United States (Apr. 12, 2000).

11. The Conference deleted the "cost bearing" stricture, which would have authorized judges to permit discovery that was disproportionate to the needs of a case only if the party seeking broader discovery paid for it. See Proposed Amendments, supra note 1, at 87-89 (Amendment to Rule 34(b)); see also Scirica Memorandum, supra note 7, at 360. See generally Thornburg, supra note 1, at 239-40; Tobias, supra note 1 , at 1441 . 
group to the Supreme Court ${ }^{12}$ the Court promulgated the revisions without change in April 2000. ${ }^{13}$

These amendments alter the present discovery regime in several significant ways. First, one of the 2000 Amendments imposing mandatory prediscovery, or automatic disclosure, requires parties to divulge less information than the 1993 version. ${ }^{14}$ Moreover, the 2000 Amendments' automatic disclosure provision applies nationally; it thus eliminates the 1993 provision that authorized each of the ninety-four federal district courts to opt out by changing the strictures in the federal rule or by rejecting those requirements altogether. ${ }^{15}$

The 2000 Amendments also narrow the scope of discovery that litigants have traditionally been able to secure. For many years, parties could acquire any information that was "relevant to the subject matter involved in the pending action." 16 The new version, however, restricts the scope of discovery to material that is "relevant to the claim or defense," and litigants can secure information that is relevant to the subject matter only after parties file motions showing good cause why they are entitled to broader discovery. ${ }^{17}$ The objectives of those who revised the rule are to limit discovery and to prevent fishing expeditions by restricting litigants to discovery that only implicates matters raised by them in the pleadings. ${ }^{18}$

One important feature of the 2000 Amendments is that those responsible for federal rule revision formulated the comparatively significant modifications reviewed above, as well as additional changes, without systematically assembling or evaluating any empirical data on the amendments ultimately prescribed. Indeed, they apparently had only a limited understanding of how the alterations will work in practice, because federal district judges had never actually applied

12. The Conference also rejected, on a 13-12 vote, deletion of the provision that would narrow discovery's scope. See Letter from Professor Thomas D. Rowe to Carl Tobias (Nov. 19, 1999) (on file with author).

13. See generally Amendments to Federal Rules of Civil Procedure, supra note 2.

14. Compare FED. R. CIV. P. 26(a) (amended 1993) (requiring the disclosure of information that is "relevant to disputed facts alleged with particularity in the pleadings") with FED. R. CIV. P. 26(a) (amended 2000) (requiring the disclosure of information that "support[s a party's] claims or defenses, unless solely for impeachment").

15. Compare FED. R. CIV. P. 26(a) (amended 1993) with FED. R. CIV. P. 26(a) (amended 2000) and FED. R. CIV. P. 26(a), Advisory Committee Note, Amendments to Federal Rules of Civil Procedure, supra note 2, at 384-85.

16. FED. R. CIV. P. 26(b)(1) (1999). Information is discoverable, if it "appears reasonably calculated to lead to the discovery of admissible evidence," even if it is not admissible at trial. Id.; see also Beckerman, supra note 8, at 513-17; Richard L. Marcus, Discovery Containment Redux, 39 B.C. L. REV. 747, 748-79 (1998); Stephen N. Subrin, Fishing Expeditions Allowed: The Historical Background of the 1938 Federal Discovery Rules, 39 B.C. L. REV. 691, 734-45 (1998).

17. See FED. R. CIV. P. 26(b); see also Thornburg, supra note 1, at 237-39; Gregory P. Joseph, Civil Rules II, NAT'L L. J., Apr. 24, 2000, at A17.

18. See FED. R. CIV. P. 26(b), Advisory Committee Note, Amendments to Federal Rules of Civil Procedure, supra note 2, at 388-90; Stotler Memorandum, supra note 4, at 27, 32-33; Edward D. Cavanagh, Obstacles in the Search for Truth; Proposed Amendments to the Federal Rules of Civil Procedure Hinder Discovery in Ways Unnecessary and Unjust, LEGAL TIMES, July 27, 1998, at 21; see also Beckerman, supra note 8, at 540-42; Subrin, supra note 16, at 734-39. 
the modifications, and attorneys and parties had not attempted to satisfy them. Of course, no evaluator has analyzed how the measures actually function.

I am criticizing neither the substance of the 2000 Amendments nor the ostensibly open process by which they took effect. The benefits and disadvantages of these changes, and the methods by which the entities developed and promulgated the alterations, have received cogent assessment elsewhere. ${ }^{19}$ No individual or institution, even those responsible for rule amendment, however, can know exactly how the new provisions will in fact operate until judges have employed them, lawyers and litigants have attempted to comply with the measures, and the devices have received careful scrutiny.

One felicitous means of ascertaining how the proposed rule modifications will work as a practical matter is readily available. Congress should adopt the 1991 proposed amendment in Federal Rule of Civil Procedure 83 that would authorize the federal districts to test promising mechanisms for five years if the courts secure Judicial Conference approval. ${ }^{20}$ Unfortunately, the rule revision entities seemed to withdraw this proposed amendment out of deference for contemporaneous experimentation involving expense and delay reduction techniques under the Civil Justice Reform Act of $1990 .^{21}$

This amendment would enable the Advisory Committee and other revisors to determine more precisely how procedural changes will work in practice. A small number, or a representative group, of districts could test apparently efficacious measures that conflict with the federal rules or statutes for a significant period of not more than five years. This practice would permit judges to apply, construe, and enforce provisions; attorneys and parties to find, master, and satisfy the strictures; and expert, independent evaluators to analyze the procedures' relative effectiveness generally and their advantages and detriments specifically. With the information that the rule amendment entities derive from that experimentation, the revisors could recalibrate contemplated alterations. Those responsible for rule amendment might then recommend formal modifications with greater confidence about how the nascent measures would operate practically, while members of the bench and bar, as well as litigants, could comment

19. See, e.g., Beckerman, supra note 8; Jeffrey W. Stempel, Ulysses Tied to the Generic Whipping Post: The Continuing Odyssey of Discovery "Reform," 64 LAW \& CONTEMP. PROBS. 197 (Spring/Summer 2001); Thornburg, supra note 1. But cf. Scirica Memorandum, supra note 7, at 360-61 (praising the "thorough process that the [Advisory] Committee followed, the quantity of information that it evaluated, and the "depth of debate over the policy considerations").

20. See Committee on Rules of Practice and Procedure, Judicial Conference of the U.S., Proposed Rules: Preliminary Draft of Proposed Amendments to the Federal Rules of Civil Procedure and the Federal Rules of Evidence, 137 F.R.D. 53, 153 (1991) (proposing the revision in Rule 83(b)). See generally A. Leo Levin, Beyond Techniques of Case Management: The Challenge of the Civil Justice Reform Act of 1990, 67 ST. JoHN's L. REV. 877, 892-94 (1993); Laurens Walker, Perfecting Federal Civil Rules: A Proposal for Restricted Field Experiments, 51 LAW \& CONTEMP. PROBS. 67 (Summer 1988).

21. See FED. R. CIV. P. 26(a)(1), Advisory Committee Note, Amendments to Federal Rules of Civil Procedure, supra note 2, at 384-85; see also Levin, supra note 20, at 891-92; A. Leo Levin, Local Rules as Experiments: A Study in the Division of Power, 139 U. PA. L. REV. 1567, 1582-83 (1991). See generally Paul D. Carrington, Learning From the Rule 26 Brouhaha: Our Courts Need Real Friends, 156 F.R.D. 295 (1994). 
on the suggested changes in a manner informed by experience of how they actually function. The recent decision to alter automatic disclosure illustrates these potential benefits. Rigorous testing and assessment of the device before it was officially imposed might have obviated the need to revise the provision so soon after its 1993 amendment. ${ }^{22}$

Congress must expeditiously revitalize the proposed revision in Rule 83 . Lawmakers should develop a new version premised on the 1991 proposal or a modified iteration of it; solicit public comment on the idea, perhaps in hearings; assess the public input that Congress receives; and pass legislation revising Rule 83. . $^{23}$ This change would improve the quality of future amendments to the Federal Rules by facilitating productive experimentation with the procedures before the Supreme Court promulgates them.

The Supreme Court recently prescribed a package of discovery revisions. Whether those amendments will prove effective remains unclear, in part because federal courts have not applied them. Congress should expeditiously rectify this situation by adopting a proposed revision in Rule 83 that would authorize experimentation with promising procedures.

22. See Griffin B. Bell et al., Automatic Disclosure in Discovery-The Rush to Reform, 27 GA. L. REV. 1, 17-18 (1992); Linda S. Mullenix, Hope Over Experience: Mandatory Informal Discovery and the Politics of Rulemaking, 69 N.C. L. REV. 795, 813-21 (1991). See generally Tobias, supra note 3, at 1611.

23. For a careful exposition of why Congress is the preferable entity to effectuate this change, see Levin, supra note 20, at 892-94; Levin, supra note 21, at 1585-87. See generally Tobias, supra note 3, at 1633. 